\title{
Sensitivity of urine-grown cells of Providencia stuartii to antiseptics
}

\author{
B. THOMAS, L. SYKES, AND D. J. STICKLER
}

From the Department of Applied Biology, University of Wales Institute of Science and Technology, Cardiff, $U K$

SUMMARY Urine-grown cultures of 23 clinical isolates of Gram-negative bacteria having a range of minimum inhibitory concentration values for chorhexidine were challenged with various concentrations of this antiseptic. The results suggest that cells of Providencia stuartii, in particular, exhibit a considerable degree of resistance to chlorhexidine under these conditions, concentrations of up to $10000-20000 \mu \mathrm{g} / \mathrm{ml}$ of urine being necessary to produce complete loss of viability of such cultures. Of the other two antiseptics tested, phenoxyethanol proved to be the more effective, the recommended use concentration of $2 \% \mathrm{v} / \mathrm{v}$ producing reductions in viable counts of greater than six logarithms in all the strains examined. It is suggested that phenoxyethanol may be a suitable alternative to the cationic agents for use in antiseptic policies for bladder management of urinary tract infections with Providencia stuartii.

Stickler and Thomas (1976) reported that strains of Providencia stuartii exhibited a degree of resistance to cationic antiseptics. This resistance was registered in standard minimum inhibitory concentration (MIC) and bactericidal tests performed under laboratory conditions. The objective of the work reported in this paper was to study the sensitivity of $\boldsymbol{P}$. stuartii to antiseptics under conditions that more closely represent those applying in clinical situations.

The main clinical problem posed by $P$. stuartii stems from its capacity to cause infections in urinary tracts that are undergoing catheterisation or some other kind of instrumentation (Dutton and Ralston, 1957; Milner, 1963; Li and Miller, 1970; Solberg and Matsen, 1971). The infections are often difficult to treat because of the extensive antibiotic resistance of these organisms (Dobrey, 1971; Graevenitz and Nourbaksh, 1972; Keane et al., 1975; British Medical Journal, 1977).

The bladder management schemes for these patients often involve cleansing the external genitalia with cationic antiseptics (Desautels, 1969; Stickler et al., 1971). Antiseptics, such as chlorhexidine, are also included in lubricating creams used to facilitate the passage of the catheter into the bladder (Gillespie et al., 1967). In some cases, chlorhexidine has been

Received for publication 15 March 1978 included in the drainage reservoirs in order to prevent the build-up of large populations of bacteria in the urine, which could then be a potential source of reinfection or cross-infection (Blandy, 1970).

The laboratory tests performed on the providencia strains employed broth-grown cells, which were tested against antiseptics in agar and broth (Stickler and Thomas, 1976). In the clinical situations described, the organisms have grown in urine, and the antiseptic is required to act in the presence of the urine growth medium. Therefore, we have attempted to test the sensitivity of providencia and other organisms under conditions that reflect these clinical situations.

\section{Material and methods}

\section{BACTERIAL STRAINS}

The providencia strains $47,67,101$, and 103 were clinical isolates reported on previously (Stickler and Thomas, 1976). Proteus mirabilis 61 (Stickler, 1974), Escherichia coli NCTC 10418, and Providencia alcalifaciens NCTC 6344 were also used in some experiments. All other strains were clinical isolates obtained from Cardiff hospitals.

MIC DETERMINATIONS

The strains to be tested were grown for 24 hours at $37^{\circ} \mathrm{C}$ in broth (Oxoid Nutrient No. 2). Volumes 
$(5 \mu l)$ of $10^{-4}$ dilutions, containing approximately $10^{3}$ viable cells, were then dropped, using a multiapplicator, onto the surface of nutrient agar (Oxoid Ltd) plates containing a range of doubling dilutions of chlorhexidine. The plates were incubated at $37^{\circ} \mathrm{C}$ overnight and then examined for growth. The lowest concentration of chlorhexidine preventing colony formation was taken as the MIC for that strain. Tests were performed in duplicate, and $E$. coli 10418 and $P$. mirabilis 61 were included as sensitive and resistant control organisms respectively.

\section{BACTERICIDAL EFFECT OF ANTISEPTICS ON} URINE-GROWN CELLS

The bacteria were grown overnight in pooled urine at $37^{\circ} \mathrm{C}$, the urine having been collected from male volunteers and sterilised by being passed through a membrane filter (Sartorious Ltd, $0.22 \mu \mathrm{m}$ pore size). Samples $(4.5 \mathrm{ml})$ of these urine cultures were mixed with $0.5 \mathrm{ml}$ of aqueous solutions of various antibacterial agents and incubated at $25^{\circ} \mathrm{C}$ for 10 minutes. At the end of this period, $0.5 \mathrm{ml}$ volumes were diluted 1 in 10 with neutraliser broth $(3 \% \mathrm{v} / \mathrm{v}$ Tween 80 in Oxoid No. 2 broth). This concentration was found to neutralise all the antiseptic solutions used in this study. After 10 minutes in the neutraliser, further dilutions were made, in broth, in order to perform viable counts on the survivors. Similar counts were also performed on control cultures not exposed to the antibacterial agents. From these results the $\log _{10}$ of reduction in viable numbers during the exposure period was calculated. The antibacterial agents used were: Chlorhexidine (ICI Ltd, a $5 \% \mathrm{w} / \mathrm{v}$ solution of chlorhexidine gluconate), Resiguard (Nicholas Laboratories Ltd), and phenoxyethanol (Phenoxetol, NIPA Laboratories $\mathbf{L t d}$ ).

\section{Results}

A collection of 23 bacterial isolates, having a wide range of sensitivities to chlorhexidine (as determined by the MIC procedure), were selected for the experiments in urine. All these strains grew well in the urine, overnight cultures typically yielding $2 \times 10^{8}$ viable cells per $\mathrm{ml}$. The sterilisation and disinfection policy, recommended by the South Glamorgan Area Health Authority Control of Infection Committee, involves the incorporation of $5 \mathrm{ml}$ of $20 \% \mathrm{w} / \mathrm{v}$ solution of chlorhexidine gluconate into a 21 capacity urine drainage bag. This represents a chlorhexidine concentration of $500 \mu \mathrm{g} / \mathrm{ml}$ when the bag is full. The 23 isolates were exposed to this concentration in the urine growth medium, and the results are shown in Table 1. Strains with high MIC values tended to retain their viability when exposed
Table 1 Bactericidal action of chlorhexidine on urine-grown cells

\begin{tabular}{|c|c|c|c|}
\hline Isolate & \multicolumn{2}{|c|}{$\begin{array}{l}\text { * } \log _{10} \text { reduction in } \\
\text { viable count on } \\
\text { exposure for } 10 \mathrm{~min} \\
\text { in } 500 \mathrm{\mu g} / \mathrm{ml} \\
\text { chlorhexidine }\end{array}$} & $\begin{array}{l}\text { MIC of } \\
\text { chlorhexidine } \\
(\mu \mathrm{g} / \mathrm{ml})\end{array}$ \\
\hline $\begin{array}{l}P . \text { stuartii } 47 \\
P . \text { stuartii } 67 \\
P . \text { stuartii } 101 \\
P . \text { stuartii } 103 \\
P . \text { stuartii } 3 / 17 \\
P . \text { stuartii } 25 / 11 \\
P . \text { stuartii } 37 / 5 \\
P . \text { stuartii } 47 / 12 \\
P . \text { stuartii } 3 / 26 \\
P . \text { alcalifaciens } \mathrm{NCTC} 6344 \\
P . \text { mirabilis } 18 / 14 \\
P . \text { mirabilis } 21 \\
P . \text { mirabilis } 61 \\
P \text { s. aeruginosas } 11 / 23 \\
P \text { s. aeruginosas } 19 / 30 \\
P \text {. aeruginosas } 25 / 10 \\
\text { K. pneumoniae } 17 / 14 \\
\text { K. pneumoniae } 51 / 1 \\
\text { K. pneumoniae } 51 / 7 \\
\text { E. coli } 2 / 26 \\
\text { E. coli } 2 / 27 \\
\text { E. coli } 2 / 29 \\
\text { E. coli } \text { NCTC } 10418\end{array}$ & \multicolumn{2}{|l|}{$\begin{array}{l}0 \cdot 88 \\
0 \cdot 16 \\
0 \cdot 16 \\
0 \cdot 68 \\
0 \cdot 25 \\
0 \cdot 41 \\
0 \cdot 11 \\
0 \cdot 47 \\
0 \cdot 20 \\
2 \cdot 93 \\
2 \cdot 11 \\
5 \cdot 30 \\
2 \cdot 45 \\
3 \cdot 24 \\
2 \cdot 70 \\
4 \cdot 85 \\
5 \cdot 83 \\
4 \cdot 18 \\
5 \cdot 36 \\
5 \cdot 79 \\
4.42 \\
5.85 \\
>6 \cdot 20\end{array}$} & $\begin{aligned} 1600 \\
1600 \\
1600 \\
1600 \\
>800 \\
800 \\
>800 \\
200 \\
800 \\
<10 \\
800 \\
20 \\
800 \\
800 \\
800 \\
200 \\
<10 \\
200 \\
200 \\
<10 \\
<10 \\
<10 \\
<10\end{aligned}$ \\
\hline \multicolumn{4}{|c|}{ *Means of three separate determinations } \\
\hline \multicolumn{4}{|c|}{$\begin{array}{l}\text { Table } 2 \text { Effect of various exposure times on the } \\
\text { bactericidal effect of chlorhexidine on urine-grown } \\
\text { cells of five Gram-negative species }\end{array}$} \\
\hline \multirow[t]{2}{*}{ Strain } & \multicolumn{3}{|c|}{$\begin{array}{l}\log _{10} \text { reduction in viable count } \\
\text { on exposure to } 500 \mathrm{\mu g} / \mathrm{ml} \\
\text { chlorhexidine for: }\end{array}$} \\
\hline & $15 \min$ & $30 \mathrm{~min}$ & $60 \mathrm{~min}$ \\
\hline $\begin{array}{l}P . \text { stuartii } 67 \\
\text { P. stuartii } 48 / 16 \\
\text { E. coli NCTC } 10418 \\
\text { P. mirabilis } 18 / 14 \\
\text { Ps. aeruginosa } 19 / 30 \\
\text { K. pneumoniae } 51 / 7\end{array}$ & $\begin{array}{c}0.0 \\
0.52 \\
>6.0 \\
4.0 \\
2.03 \\
>6.0\end{array}$ & $\begin{aligned} & 0 \cdot 1 \\
& 0.54 \\
> & 6 \cdot 0 \\
> & 6 \cdot 0 \\
& 2 \cdot 50 \\
> & 6.0\end{aligned}$ & $\begin{aligned} & 0.2 \\
& 0.58 \\
> & 6.0 \\
> & 6.0 \\
& 3.09 \\
> & 6.0\end{aligned}$ \\
\hline
\end{tabular}

to the antiseptic in urine. In fact, there was a significant negative correlation between the MIC values and the reductions in viable cells obtained (Kendal's rank correlation, $\mathrm{r}=\mathbf{0 \cdot 8 2}$, probability of this result being due to chance $P \leqslant 0.05$ ). Exposure $\mathcal{N}$ time greater than 10 minutes did not result in any $N$ significant further loss of viability (Table 2 ).

Table 3 reports the results of attempts to discover whether higher concentrations of chlorhexidine would be more effective against five of the providencia isolates. The data suggest that a concentration of $20000 \mu \mathrm{g} / \mathrm{ml}$ was necessary to induce complete loss of viability in all strains.

When considering alternative antiseptics, the choice is limited to those that are non-irritant to the skin and membranes of the urinary tract. Table 4 
Table 3 Bactericidal action of various concentrations of chlorhexidine on urine-grown cells of $P$. stuartii

\begin{tabular}{ccccc}
\hline Strain & $\begin{array}{l}\text { * Log } \\
\text { to reduction in viable count on exposure for } 10 \mathrm{~min} \\
\text { to the following concentrations of chlorhexidine: }\end{array}$ \\
\cline { 2 - 5 } & $1000 \mu \mathrm{g} / \mathrm{ml}$ & $5000 \mu \mathrm{g} / \mathrm{ml}$ & $10000 \mu \mathrm{g} / \mathrm{ml}$ & $20000 \mu \mathrm{g} / \mathrm{ml}$ \\
\hline 67 & 0.45 & 3.6 & 4.67 & $>6$ \\
101 & 1.26 & 4.5 & $>6.0$ & - \\
$3 / 17$ & 0.88 & 3.5 & $>6.0$ & - \\
$37 / 5$ & 2.15 & $>6.0$ & - & - \\
$25 / 11$ & 3.17 & $>6.0$ & - & - \\
\hline
\end{tabular}

* Means of three separate determinations

-Not tested

Table 4 Bactericidal action of phenoxyethanol and Resiguard on urine-grown cells of five Gram-negative species

\begin{tabular}{|c|c|c|c|c|}
\hline \multirow[t]{2}{*}{ Strain } & \multicolumn{4}{|c|}{$\begin{array}{l}\text { *og }_{10} \text { reduction in viable count on } \\
\text { exposure for } 10 \mathrm{~min} \text { to: }\end{array}$} \\
\hline & $\begin{array}{l}\text { Resiguard } \\
\text { (1/160 } \\
\text { dilution) }\end{array}$ & $\begin{array}{l}\text { Resiguard } \\
\text { (1/80 } \\
\text { dilution) }\end{array}$ & $\begin{array}{l}\text { Phenoxy- } \\
\text { ethanol } \\
(1 \% v / v)\end{array}$ & $\begin{array}{l}\text { Phenoxy- } \\
\text { ethanol } \\
(2 \% v / v)\end{array}$ \\
\hline P. stuartii 67 & 0.4 & 0.17 & $5 \cdot 5$ & $>6.0$ \\
\hline P. stuartii 101 & - & 0.06 & - & $>0.0$ \\
\hline P. stuartii $3 / 17$ & - & 0.47 & - & $>6.0$ \\
\hline P. stuartii $37 / 5$ & - & $3 \cdot 17$ & - & $>6.0$ \\
\hline P. stuartii $25 / 11$ & - & 1.67 & - & $>6.0$ \\
\hline P. mirabilis $18 / 14$ & $3 \cdot 8$ & - & $1 \cdot 7$ & $>6.0$ \\
\hline Ps. aeruginosa $19 / 30$ & $1 \cdot 0$ & - & 0.0 & $>6.0$ \\
\hline K. pneumoniae $51 / 7$ & $3 \cdot 0$ & - & $>6.0$ & $>6.0$ \\
\hline E. coli NCTC 10418 & $>6.0$ & - & $0 \cdot 3$ & $>6.0$ \\
\hline
\end{tabular}

* Means of three separate determinations

- Not tested

shows the results of testing two possible alternatives, Resiguard and phenoxyethanol, against urine-grown cells of the five providencia strains and selected strains of other species.

\section{Discussion}

The results of the MIC determinations on the 23 isolates (Table 1) confirm earlier reports that resistance to chlorehexidine can be recorded in $P$. stuartii (Stickler and Thomas, 1976), P. mirabilis (Gillespie et al., 1967; Stickler, 1974), and Pseudomonas aeruginosa (Bentley et al., 1968). The results of the bactericidal tests of chlorhexidine on urine-grown cells (Tables 1 and 3) indicate that this resistance is likely to be manifested under conditions where the antiseptic is used in bladder management procedures. Isolates of $\boldsymbol{P}$. stuartii were the least affected by chlorhexidine, concentrations of 10000 to $20000 \mu \mathrm{g} / \mathrm{ml}$ of urine being necessary to produce appreciable killing of some strains.

Of the alternative antiseptics tested in this study (Table 4), Resiguard at a 1 in 80 dilution of the commercial concentrate (the lowest recommended dilution for use as an antiseptic), had a minimal effect on the urine-grown cells of $\boldsymbol{P}$. stuartii. Phenoxyethanol $(2 \% \mathrm{v} / \mathrm{v})$, however, produced a reduction of at least six logarithms in the viable counts of the chlorhexidine and Resiguard resistant strains. It was similarly successful in reducing the viable counts of urine-grown cultures of the other species tested.

The effectiveness of phenoxyethanol against certain Gram-negative bacteria has been known for some time. Berry (1944) found that its activity was greatest against Pseudomonas pyocyanea (aeruginosa) and that there was no loss of activity in the presence of $20 \%$ serum. In clinical trials, Gough et al. (1944) reported that an aqueous solution of $2 \cdot 2 \%$ phenoxyethanol was effective for the treatment of burns and superficial wounds infected with Ps. pyocyanea, although Gram-positive organisms were apparently not affected. These authors found that this concentration of phenoxyethanol was not irritant in these situations. In view of this, it seems that phenoxyethanol may be suitable for use in circumstances where there is a possibility of contact with the membranes of the urinary tract.

In conclusion, it seems that chlorhexidine may not be effective for the prevention of infection and cross-infection of urinary tracts where certain Gram-negative organisms, particularly $P$. stuartii, are a problem. Phenoxyethanol may be one suitable alternative, although its relative lack of activity against Gram-positive bacteria may necessitate its being used in combination with a second, compatible antibacterial agent.

We are grateful to Dr J. M. H. Boyce and the technical staff of the bacteriology laboratories at St. David's Hospital, Cardiff, for supplying many of the strains used in this study. We acknowledge the technical assistance of $\mathrm{Mr}$ G. D. Thomas in part of this work, and we are indebted to the Committee of the Welsh Scheme for the Development of Health and Social Research for financial support.

\section{References}

Bentley, M., Davies, A., Field, B. S., and Roberts, W. (1968). Characteristics of growth of a Pseudomonas species in culture media containing chlorhexidine. Biochemical Journal, 110, p. 45.

Berry, H. (1944). Antibacterial values of ethylene glycol mono-phenyl ether. Lancet, 2, 175-176.

Blandy, J. P. (1970). Catheterisation. British Journal of Hospital Medicine, 4, 179-182.

British Medical Journal. (1977). Unusual infection in intensive care unit. British Medical Journal, 1, 111. 
Desautels, R. E. (1969). The causes of catheter-induced urinary infections and their prevention. Journal of Urology, 101, 757-760.

Dobrey, R. (1971). A hospital study of the Providence group with particular reference to sub-grouping and the possible presence of R-factors. Canadian Journal of Medical Technology, 33, 177-187.

Dutton, A. A. C., and Ralston, M. (1957). Urinary tract infection in a male urological ward. Lancet, 1, 115-119.

Gillespie, W. A., Lennon, G. G., Linton, K. B., and Phippen, G. A. (1967). Prevention of urinary infection by means of closed drainage into a sterile plastic bag. British Medical Journal, 3, 90-92.

Gough, J., Berry, H., and Still, B. M. (1944). Phenoxetol in the treatment of Pyocyanea infections. Lancet, 2, 176-178.

Graevenitz, A. von, and Nourbakhsh, M. (1972). Antimicrobial resistance of the genera Proteus, Providencia and Serratia with special reference to multiple resistance patterns. Medical Microbiology and Immunology, 157, 142-148.

Keane, C. T., English, L. F., and Wise, R. (1975). Providencia stuartii infections (Letter). Lancet, 2, 1045.

Li, K., and Miller, C. (1970). Pathogenic bacteria and their sensitivity patterns in a hospital population of geriatric patients with chronic disease. Journal of the American Geriatrics Society, 18, 286-294.

Milner, P. F. (1963). The differentiation of Enterobacteriaceae infecting the urinary tract: a study in male paraplegics. Journal of Clinical Pathology, 16, 39-45.

Solberg, C. O., and Matsen, J. M. (1971). Infections with Providence bacilli: a clinical and bacteriological study. American Journal of Medicine, 50, 241-246.

Stickler, D. J. (1974). Chlorhexidine resistance in Proteus mirabilis. Journal of Clinical Pathology, 27, 284-287.

Stickler, D. J., and Thomas, B. (1976). Sensitivity of Providence to antiseptics and disinfectants. Journal of Clinical Pathology, 29, 815-823.

Stickler, D. J., Wilmot, C. B., and O'Flynn, J. D. (1971). The mode of development of urinary infection in intermittently catheterised male paraplegics. Paraplegia, 8, 243-252.

Requests for reprints to: Dr D. J. Stickler, Department of Applied Biology, University of Wales Institute of Science and Technology, King Edward VII Avenue, Cardiff CF1 3NV 